\title{
The Effect of Internal Auditor Independence on Effectiveness of Government Internal Audit: Group Cohesiveness As An Intervening Variable (Case Study At The Regional Inspectorates At Java Island)
}

\author{
Moh. Ubaidillah \\ Universitas PGRI Madiun \\ ubaidillahmoh@rocketmail.com \\ Ari Kuncara Widagdo \\ Fakultas Ekonomi Bisnis Universitas Sebelas Maret \\ Email:widagdo2002@yahoo.com
}

\begin{abstract}
The objective of this study is to examine the effect of auditor independence, group cohesiveness, and individual factors on internal audit effectiveness of regional inspectorates. In addition, this study also intends to examine whether group cohesiveness mediates relationship between auditor independence and internal audit effectiveness. Population of this study is regional inspectorates located in some regencies/municipalities in Central Java Province and East Java Province, Indonesia. Method of analysis of this study is structural equation modeling by using Smart PLS. The results indicate that, as predicted, auditor independence has a positive and significant relationship with internal audit effectiveness. Interestingly, this study proves that group cohesiveness partially mediates relationship between auditor independence and internal audit effectiveness. Unfortunately, individual factors (i.e. level of education and work experience) do not have significant relation with audit effectiveness.
\end{abstract}

Keywords: Audit effectiveness, auditor independence, group cohesiveness.

\section{INTRODUCTION}

Local government internal auditor, which is known also as regional inspectorate, is a unit conducting local government oversight. Regional inspectorate has the task of conducting the general supervision of the local government and other duties assigned by the head of the region (Falah, 2005). The role and functions of the inspectorate of provinces, districts/cities, in general, governed by Article 4 of Regulation of the Minister of Interior No. 64 of 2007. In this article, it is stated that, in carrying out supervisory duties of government affairs, inspectorates provincial or inspectorates district/city have a function as follows: first, planning surveillance program; second, policy formulation and monitoring facilities; and third, examination, investigation, testing, and assessment of supervisory duties.

However, in reality, the roles of the regional inspectorate are being questioned as hundreds of officers in Indonesia caught in corruption. In the period 2009-2014, of the 439 cases handled by the Corruption Eradication Commission, 45.33 percent involves government administrators. The data of the Ministry of Internal Affair shows, since decentralization in 2014, as many as 318 heads/deputy heads of the region have involved in corruption. The regional inspectorate seems be absentee in preventing rampant irregularities. In fact, the regional inspectorate should be a means of early detection. (Anggoro, 2015).

One of things that led to the ineffectiveness of the regional inspectorate is auditor independence issue of auditor of inspectorate. At this time, the regional inspectorate is an 
Widagdo: The Effect of Internal Auditor Independence on Effectiveness... unit under the head of the region. In this condition. infreguently recommendations issued by the regional inspectorate are not responded by the head of the region. In addition, the regional inspectorate is often considered an enemy. Thus, the auditors of regional 
inspectorate might get sanctions such as discharged, and mutation to the remote area.. Therefore, the auditors of regional inspectorate should adhere to what was ordered by the head of the region to avoid the sanctions. In such situations, the independence of the auditors of regional inspectorate in carrying out tasks is questioned. In fact, the auditor independence is one of the essential elements for the auditors of regional inspectorate in carrying of auditing of local government budget (Anggoro, 2015).

Various studies on effectiveness of internal audit have been carried out outside and within Indonesia, for example, Cohen and Sayag (2010), Mihret and Yismaw (2007), Salameh et al. (2011), Badara and Saidin (2014), and Feizizadeh (2012). However, some prior studies on the effect of auditor independence on effectiveness of the audit of regional inspectorate in Indonesia reveal inconsistent finding. Some prior studies prove that auditor independence is significantly influence the effectiveness of audit. It indicates that the independence of the auditor is very important in doing financial auditing. In contrast, other studies reveal that auditor independence does not affect the effectiveness of regional inspectorate audit.

In addition to auditor independence, some researchers have tried to examine the relationship between the individual factors with the effectiveness of the auditor. For example, some prior studies examine effect of level of education and auditor experience on the effectiveness of the audit or performance audit (e.g. Mulyono, 2009; Wicaksana and Budiartha, 2015). Based on those studies, the level of education and work experience has a positive effect on the effectiveness of the audit or performance audit. This suggests that education and experience will facilitate the audit; the higher the level of education and experience, the better in conducting the audit.

Other variables may affect the effectiveness of the internal audit, namely cohesiveness of the group. However, there are limited prior studies regarding the effect of group cohesiveness on the effectiveness of the internal audit particularly in Indonesia. Only one study conducted by Wibowo (2012) reveal that the group cohesiveness has a positive effect on the performance of auditors. This suggests that, in an audit team, the absence of group cohesion in the audit team might cause ineffectiveness of the audit.

Based on the above explanation, prior studies on the effect of auditor independence on effectiveness of internal audit are not consistent. Therefore, researchers argue that the inconsistent results of auditor independence because of the presence of another variable that may affect the relationship. Therefore, this study will examine whether group cohesiveness mediates the relationship between the auditor independence and effectiveness of the internal audit.

\section{LITERATURE REVIEW}

Internal Auditor Effectiveness and Auditor independence. The effectiveness of the audit is an achievement or completed the audit in accordance with the rules applicable. According to the Professional Standards of Internal Audit (Tugiman, 1997), there are nine indicators of the effectiveness of internal audit, namely (1) feasibility and significance of inspection findings and its recommendations, (2) the response of the object being examined, (3) professionalism auditor, (4) warning, (5) the cost-effectiveness of inspection, (6) the development of personnel, (7) the feedback from other management, (8) the increased number of inspections, and (9) the achievement of the inspection program. 
Auditor independence is an attitude that is not impartial or that is not controlled by the outside or inside ourselves auditor himself. Mulyadi (2002) states that auditor independence means a mental attitude that is free from influence, not control the other party, does not depend on others. The auditor independence also means that their honesty in the audit in considering the facts and considerations impartiality of the auditors themselves to formulate and express opinions. Arens et al. (2000) define auditor independence in auditing as a use of perspective that is not biased in the implementation of audit testing, evaluation of the test results, and reporting of audit findings. According to Messier et al. (2012), auditor independence is a term often used by professional auditor. The auditor independence tends to avoid relationships that might interfere with the objectivity of the auditor.

Hypothesis Development. Auditor independence. Based on agency theory, in a democracy country, parliament as a representative of the community can be considered as a principal, whereas government is an agent. Both are different institutions and each function is interrelated to the survival of a country. The function of the government itself is providing services to the public in accordance with regulations, while the function of Parliament is to oversee government performance. This will probably lead to asymmetry of information that creates agency problems. The information presented authorities may require verification of the other party. Therefore, an independent party is needed to overcome asymmetry information. In the context of local government, one of the independent parties is regional inspectorate. In this such condition, the regional inspectorate auditors should be able to act independently in carrying out their functions. In order to carry out an audit, auditors of regional inspectorate should have a greater degree of auditor independence. Yusri (2013) reveal that auditor independence might improve the performance of the auditor of regional inspectorate. Similarly, Agustin (2010) finds that the auditor independence affects the effectiveness of the internal audit. Therefore, the hypothesis is formulated as follows:

H1: The auditor's auditor independence has a positive influence on the effectiveness of the audit of regional inspectorate.

Auditor independence and Group Cohesiveness. The working group has become a very important thing today. Working in a group course provides advantages compared to working alone. Baron and Byrne (2004) define that group is as a group of people who are perceived bonded to one another in a coherent unit to a certain degree. Factor that causes the last group members in the group is called cohesion. According to George and Jones (2002), group cohesiveness is a member of a group that has a fascination with each other. A working group with high cohesiveness is mutually attracted to each member, whereas the low cohesiveness of working groups is not mutually attracted to each other.

The audit team is a working group that should have a high cohesion. The cohesiveness is mainly formed due to homogeneous group. Homogeneity can be created because of similarities in background or shared values and goals posed by members of the group. When members have the same properties, then cohesion will increase rapidly and will realize the effectiveness or performance. The audit team is a group of auditors consisting of people who have some similarities, such as educational background, and values/ethical code. The educational background of the auditor usually come from the homogenous education, namely accounting education In addition, auditor independence is 
the value/code of conduct that should be owned by every auditor. The higher the level of auditor independence of the auditor, the audit team cohesiveness will also be high, because the homogeneity is also high. In the end, the high cohesiveness will increase effectiveness of internal audit. As an evidence, Wibowo (2012) find that the cohesiveness of the work group has a positive effect on the performance of auditors. Based on the description above, the hypothesis can be formulated as follows:

H2: The group cohesiveness mediates relation between auditor's auditor independence and the effectiveness of the audit of regional inspectorate.

Individual Factors. Individual factors in this study are audit experience and education level. Audit experience is a job audit Waku a need for long to understand very well about the audit issues so familiar and easily auditor in conducting the audit. According Kusumastuti (2008), the experience is a trip in the quotation by someone of the events experienced in the course of his life. Long working experience is an experience of auditor calculated based on a time or year. An experienced auditor will be able to add to and expand the auditor's knowledge in the field of accounting and auditing field.

The level of education is also needed to determine the effectiveness of the audit. The more knowledge gained will facilitate the auditor in solving problems in performing audit engagements. According Gorda (2004) in Laksmi, (2010), education is an activity for improvement and developing human resources by improving the ability and understanding of general knowledge and knowledge of the economy including the improvement of theoretical knowledge and skills as an effort to solve the problems facing the company.

Audit experience and level of education is the competence or the ability to carry out the audit task, because with these competencies auditor will find out which one is right and wrong in auditing financial statements. The higher level of audit experience and level of education also will be easy to realize the effectiveness of the audit regional inspectorate officials.

H3: Individual factor has a positive effect on the effectiveness of the audit of regional inspectorate.

Research Framework. Based on a literature review and hypothesis development above, in this study, auditor independence of auditor is an independent variable that influence the effectiveness of audit of regional inspectorate. The group cohesiveness works as an intervening variable that mediates the relationship between auditor's auditor independence and the effectiveness of audit of regional inspectorate. In addition, the study includes individual factors as independent variable that influence the effectiveness of audit of regional inspectorate.

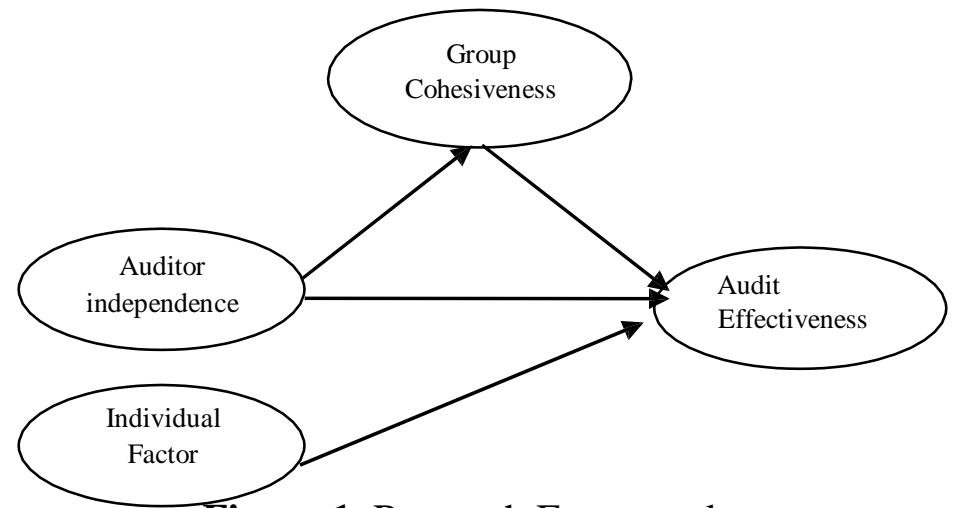

Figure 1. Research Framework 


\section{METHOD}

Population and Data. The population in this study is the auditors of regional inspectorate in some regencies in Java island, namely Sragen, Wonogiri, Boyolali, Ngawi, Magetan, Pacitan, Ponorogo and Madiun. The reason for choosing these regencies is due to a few cases of corruption in such regions and the ease of access to get sample. This study employs all member of population as sample. This research is a quantitative study using primary data. Method of data collection is a questionnaire method. The questionnaire was given to the respondent and the respondent will then fill it in accordance with the opinions and perceptions of respondents.

The questionnaire to measure the effectiveness of audit is built based on the indicator of Internal Control System of Government based on the Indonesian Government Regulation No. 60 of 2008. In this study, the group cohesiveness variable is measured by adopting instrument of Forsyth (2010). This variable is measured by two dimensions, namely task cohesiveness and group cohesiveness. The measurement of auditor independence is adopted from the instrument of Yusri (2013). The individual factors consist of the level of education and work experience. In this study, the level of education is formal education that will be measured by giving a value ranging from a high school education to $S 3$, namely senior high school $=1$, diploma $=2$, undergraduate $=3$, master $=$ 4 , and doctoral $=5$. The audit experience in this study were measured using 3 levels: less than 2 years: $1,2-5$ years:2 and more than 5 years :3. Before the distribution of questionnaire to prospective respondents, the researchers carry out a pilot test to prospective respondents. In this study, a pilot test was conducted on June 1, 2015 until the date of June 8, 2015. The pilot test questionnaires were distributed to 25 respondents, but only 20 complete questionnaires were obtained. The analyze of the reliability and validity indicated that all questions are valid and reliable.

Data Analysis. In this study, analysis of data uses Partial Least Square (PLS). PLS is a model equation of Structural Equation Modeling (SEM) based components or variants. According Ghozali (2006), PLS goal is to help researchers for predictive purposes. Thus, it is consistent with the objective of this study to predict the relationship of several variables that affect the effectiveness of internal audit.

\section{RESULTS AND DISCUSSION}

Distribution of Respondents. The questionnaire was distributed to 143 respondents, but the complete questionnaire was 120. The detail is on Table 1.

\begin{tabular}{|c|c|c|c|c|}
\hline \multirow{3}{*}{$\begin{array}{c}\text { Regency / } \\
\text { City }\end{array}$} & \multicolumn{4}{|c|}{ Table 1. Distribution of Respondent } \\
\hline & Number of & Returned & Incomplete & Complete \\
\hline & auditors & questionnaire & questionnaire & questionnaire \\
\hline Ngawi & 13 & 13 & - & 13 \\
\hline Ponorogo & 17 & 12 & 1 & 11 \\
\hline Magetan & 21 & 21 & 1 & 20 \\
\hline $\begin{array}{l}\text { Kota } \\
\text { Madiun }\end{array}$ & 21 & 21 & - & 21 \\
\hline
\end{tabular}




\begin{tabular}{lcccc} 
Pacitan & 9 & 9 & - & 9 \\
Sragen & 20 & 18 & 2 & 16 \\
Boyolali & 24 & 19 & 3 & 16 \\
Wonogiri & 18 & 14 & - & 14 \\
Total & 143 & 127 & 7 & 120 \\
\hline
\end{tabular}

Data Analysis. Evaluation of Measurement Model (Outer Model). The outer model is a stage to determine the validity and reliability of latent variables. To determine the validity, discriminant validity was measured by using the AVE and Communality. The requirements to meet the validity must be above 0.50 . The Table 2 below shows that all the variables above 0.50 , then they are valid.

Table 2. AVE and Communality

\begin{tabular}{ccc}
\hline & AVE & Communality \\
\hline EF & 0,58091 & 0,580909 \\
EF_A & 1 & 1 \\
EF_B & 0,77602 & 0,776017 \\
EF_C & 0,79315 & 0,793147 \\
EF_D & 0,85679 & 0,856786 \\
EF_E & 0,78027 & 0,780273 \\
EF_F & 0,80398 & 0,803978 \\
EF_G & 0,86112 & 0,861122 \\
ID & 1 & 1 \\
IN & 0,54749 & 0,547489 \\
IN_A & 0,62856 & 0,628555 \\
IN_B & 0,6285 & 0,628504 \\
IN_C & 0,80213 & 0,802126 \\
KH & 0,60276 & 0,602756 \\
KH_A & 0,66605 & 0,666046 \\
KH_B & 0,65681 & 0,656812 \\
\hline
\end{tabular}

The test of reliability in SmartPLS uses two evaluations, namely reliability and cronbach alpha that require loading factor above 0.70 . Table 3 shows that all of variables are above 0.70 .

Table 3. The Result of Cronbach Alpha and

\begin{tabular}{ccc}
\multicolumn{3}{c}{ Composite Reliability } \\
\hline & $\begin{array}{c}\text { Cronbach } \\
\text { Alpha }\end{array}$ & $\begin{array}{c}\text { Composite } \\
\text { Reliability }\end{array}$ \\
\hline EF & 0,93928 & 0,947193 \\
EF_A & 1 & 1 \\
EF_B & 0,71228 & 0,873853 \\
EF_C & 0,739345 & 0,884638 \\
EF_D & 0,832876 & 0,92287
\end{tabular}




\begin{tabular}{ccc}
\hline \hline EF_E & 0,718999 & 0,876557 \\
EF_F & 0,756436 & 0,891333 \\
EF_G & 0,838829 & 0,925378 \\
ID & 1 & 1 \\
IN & 0,89423 & 0,914872 \\
IN_A & 0,706023 & 0,835011 \\
IN_B & 0,704195 & 0,835252 \\
IN_C & 0,87635 & 0,923977 \\
KH & 0,932979 & 0,943095 \\
KH_A & 0,750127 & 0,85638 \\
KH_B & 0,925017 & 0,938588 \\
\hline
\end{tabular}

Structural Model (Inner Model). The structural models were evaluated using the R-square $\left(\mathrm{R}^{2}\right)$ to construct the dependent, and the t test for structural lines of coefficient parameters. $\mathrm{R}^{2}$ can be used to assess substantive effect of latent independent variables on the latent dependent variable. Table 4 shows that the lowest is 0.436818 , whereas the highest $\mathrm{R}^{2}$ is 0.968889 . These results indicate that the structural model is quite good.

Table 4. R-Square

\begin{tabular}{cc}
\hline & R Square \\
\hline EF & 0,950865 \\
EF_A & 0,436818 \\
EF_B & 0,661585 \\
EF_C & 0,841128 \\
EF_D & 0,632766 \\
EF_E & 0,818909 \\
EF_F & 0,751061 \\
EF_G & 0,690506 \\
ID & \\
IN & \\
IN_A & 0,706597 \\
IN_B & 0,854692 \\
IN_C & 0,828853 \\
KH & 0,965901 \\
KH_A & 0,774515 \\
KH_B & 0,968889 \\
\hline
\end{tabular}

Evaluation of Goodness of Fit. Following is result of the calculation of goodness of fit:

Gof = Error! Reference source not found.

Gof $=$ Error! Reference source not found.

Gof $=$ Error! Reference source not found.

Gof $=0.763066$

The result of Gof is 0.763066 that is higher than 0.50 , then the model is fit. 
Hypothesis Testing. Based on Table 5, it can be seen that effect of the individual factors on the audit effectiveness has a t-statistic value of 0.55324 and path coefficient of 0.008723 . This suggests that the result of t-statistic is not significant because it is less than 1.96. The effect of auditor independence on audit effectiveness has a positive and significant because t-statistic is 2.951428 and path coefficient of 0.372806 . Furthermore, auditor independence also has a positive and significant effect on the group cohesiveness because t-statistic value is 313.718766 and the value of the coefficient path is 0.982803 . The group cohesiveness has a positive and considerable influence on the audit effectiveness because t-statistic value is 4.752799 and path coefficient is 0.984322 .

Table 5. The Path Coefficients and T-Statistic

\begin{tabular}{cccccc}
\cline { 3 - 6 } & $\begin{array}{c}\text { Original } \\
\text { Sample } \\
(\mathrm{O})\end{array}$ & $\begin{array}{c}\text { Sample } \\
\text { Mean (M) }\end{array}$ & $\begin{array}{c}\text { Standard } \\
\text { Deviation } \\
(\text { STDEV })\end{array}$ & $\begin{array}{c}\text { Standard } \\
\text { Error } \\
(\text { STERR })\end{array}$ & $\begin{array}{c}\text { T Statistics } \\
(\mid \mathrm{O} / \text { STERR })\end{array}$ \\
\hline ID -> EF & 0,00872 & 0,02174 & 0,01577 & 0,01577 & 0,553246 \\
IN -> EF & 0,37281 & 0,34761 & 0,12631 & 0,12631 & 2,951428 \\
IN -> KH & 0,9828 & 0,98268 & 0,00313 & 0,00313 & 313,718766 \\
KH -> EF & 0,60561 & 0,63049 & 0,12742 & 0,12742 & 4,752799 \\
\hline
\end{tabular}

Following Hair et al. (2014), to determine the effect of mediation role of group cohesiveness, there are three questions that needs to answer: (1) Is the direct effect between auditor independence and audit effectiveness significant when the mediator variable (group cohesiveness) is excluded from the path model, (2) Is the indirect effect via the mediator variable significant after the group cohesiveness has been included in the path model and (3) How much of the direct effect does the indirect effect via the mediator absorb?

To answer the first question, the group cohesiveness was excluded from the path model and run the bootstrapping routine with the previously described specifications. As a result, the t-statistic of direct effect between auditor independence and audit effectiveness is 3,155601 that is higher than 1.96. Answering the second question requires re-estimating the full model (i.e., with the mediator included) and testing the indirect effect's significance. The corresponding boot-strapping results indicate that t-statistic of the indirect effect is 2,951428 that is higher than 1.96 (see Table 5). Finally, the variance accounted for (VAF) was computed using the following formula:

$$
\begin{aligned}
V A F & =\frac{\text { indirect } \text { effect }}{\text { indirect } \text { effect }+ \text { direct } \text { effect }} \\
V A F & =\frac{0,595198273}{0,595198273+0,968} \\
V A F & =\frac{0,595198273}{1,563202273}
\end{aligned}
$$

Error! Reference source not found.0,380755762

$$
\begin{aligned}
& V A F=0,38 \\
& V A F=38 \%
\end{aligned}
$$


The results of this final analysis step yield a VAF value of 0.38 or 38 percent, which, according to Hair et al. (2014), suggests that the group cohesiveness partially mediates the relationship between auditor independence and audit effectiveness.

Table 6. Total Effect (Mean, STDEV, T-Values)

\begin{tabular}{cccccc}
\cline { 5 - 6 } & $\begin{array}{c}\text { Original } \\
\text { Sample } \\
(\mathrm{O})\end{array}$ & $\begin{array}{c}\text { Sample } \\
\text { Mean } \\
(\mathrm{M})\end{array}$ & $\begin{array}{c}\text { Standard } \\
\text { Deviation } \\
(\text { STDEV })\end{array}$ & $\begin{array}{c}\text { Standard } \\
\text { Error } \\
(\text { STERR })\end{array}$ & $\begin{array}{c}\text { T Statistics } \\
(\mid \mathrm{O} / \text { STERR })\end{array}$ \\
\hline $\mathrm{ID}$-> EF & 0,00872 & 0,00311 & 0,024072 & 0,024072 & 0,362385 \\
$\mathrm{IN}->\mathrm{EF}$ & 0,968 & 0,96925 & 0,008564 & 0,008564 & 113,03839 \\
$\mathrm{IN}$-> KH & 0,9828 & 0,98335 & 0,003001 & 0,003001 & 327,543539 \\
$\mathrm{KH}$-> EF & 0,60561 & 0,60209 & 0,127524 & 0,127524 & 4,749021 \\
\hline
\end{tabular}

\section{CONCLUSION}

The result of analysis indicates that the auditor independence has a positive and significant effect on the audit effectiveness of regional inspectorate. The positive influence suggests that, if the auditor's auditor independence is high, it will increase the effectiveness of the audit. It implies that $t$ the auditor independence of auditors of regional inspectorate has a very important role in enhancing the effectiveness of the internal audit on local government. This finding is consistent with prior studies conducted by Endah and Heru (2011) and Yusri (2013). In terms of mediation variable, the result of analysis reveals that group cohesiveness partially mediates relationship between auditor independence and audit effectiveness. This auditor of regional inspectorate has homogeneity in values/ethics and education background might create a group cohesiveness.

Based on the hypothesis test result, the individual factors do not affect the effectiveness audit of regional inspectorate officials. Thus, the audit experience and education level have significant effect on the effectiveness of the audit. This is in line with Sunarto (2003) that competence only is not enough, but the auditor must be independent, because he was carrying out work in the public interest. In addition, Arens et al. (2006) state that, without auditor independence, audit work will not have a value.

This study has several limitations that should consider in interpreting the results. First, this research was carried out only in a few districts/cities in Central Java and East Java, so the results may not be applicable in other areas. Accordingly, further research may extend the area, so that the results can be generalized. Second, in collecting data, it was difficulty of controlling the answer given by the auditor. Some of the answers given auditors through questionnaires may not reflect their perception, because the researchers did not directly supervise. Therefore, future studies should directly supervise the filling of the questionnaires. Related insignificant individual variable factors, further research may need to place the individual factors as moderating variable.

\section{REFERENCES}

Arens, Elder, dan Bealey (2006) Auditing and assurance service: Integrated approach. New Jersey: Pearson Prentice Hall. 
Anggoro, A. P. (2015) Inspektorat belum paripurna cegah korupsi. http://nasional.kompas.com/read/2015/03/26/15000041/Inspektorat.Belum.Paripurna .Cegah.Korupsi. Download at 13 November 2015.

Badara, M.S. dan Saidin, S.Z. (2014) "Empirical evidence of antecedents of internal audit effectiveness from Nigerian perspective". Middle-East Journal of Scientific Research, 19(4).

Baron, R.A., dan Byrne, D. (2004). Social psychology, $10^{\text {th }}$ eds. New Jersey: Pearson.

Cohen, A. dan Sayag, G. (2010). "The effectiveness of internal auditing: An empirical examination of its determinants in Israeli organisations". Australian Accounting Review 50 (20), 62-79

Endah Wulandari dan Heru Kurnianto Tjahjono. (2011). "Pengaruh kompetensi, independensi dan komitmen organisasi terhadap kinerja auditor pada BPKP Perwakilan DIY". Universitas Muhammadiyah Yogyakarta 1 (1)

Falah,S. (2005).'Pengaruh budaya orientasi etika sensitivitas etika. Tesis. Tidak dipublikasikan. Semarang: Universitas Diponegoro Semarang

Feizizadeh, A. (2012). "Strengthening internal audit effectiveness". Indian Journal of Science and Technology, 5(5)

Forsyth, D.R. (2010). Group dynamics. $5^{\text {th }}$ eds. Wadsworth: Cengage Learning

George dan Jones. (2002). Organizational Behavior. New Jersey: Prentice-Hall

Ghozali, I. (2006). Structural equation modeling, metode alternatif dengan partial least square. Edisi 2. Semarang: Badan Penerbit Universitas Diponegoro.

Hair, J. F., Jr., Hult, G. T. M., Ringle, C. M., dan Sarstedt, M. (2014). A primer on partial least squares structural equation modeling (PLS-SEM). Thousand Oaks, CA: SAGE Publications Ltd.

Kusumastuti, R. D. (2008). Pengaruh pengalaman, komitmen profesional, etika organisasi, dan gender terhadap pengambilan keputusan etis auditor. Jakarta.UIN Syarif Hidayatullah.

Laksmi D. G. (2010). Pengaruh tingkat pendidikan, pelatihan kerja, pengalaman kerja, dan profesionalisme petugas pemeriksa pajak pada penyelesaian pemeriksaan pajak di Kantor Pelayanan Pajak Pratama se- Bali. Skripsi. Tidak dipublikasi. Denpasar: Jurusan Akuntansi pada Fakultas Ekonomi Universitas Udayana.

Messier, F.W., V.S. Glover, dan F.D. Prawitt. (2012). Auditing and assurance services: A systematic approach, 8 eds. New York: Mc GraHill

Mihret, G. D. dan Yismaw, W. A (2007). "Internal audit effectiveness: An Ethiopian public sector case study" .Managerial Auditing Journal, 22 (5), 470-484. ISSN 0268-6902

Mulyadi. (2002). Auditing, edisi keenam, Buku 1, Jakarta: Salemba Empat

Mulyono, A (2009). Analisis faktor-faktor kompetensi aparatur inspektorat dan pengaruhnya terhadap kinerja inspektorat Kabupaten Deli Serdang. Tesis. Tidak dipublikasi. Sumatra Utara: Sekolah Pascasarjana Universitas Sumatra Utara

Peraturan Menteri Dalam Negeri Nomor 64 Tahun 2007 tentang Pedoman teknis organisasi dan tata kerja inspektorat provinsi dan kabupaten/kota.

Peraturan Pemerintah Republik Indonesia Nomor 60 Tahun 2008 tentang Sistem pengendalian intern pemerintah

Salameh, R., Al-Weshah, G., Al-Nsour, M dan Al-Hiyari, A. (2011). “Alternative internal audit structures and perceived effectiveness of internal audit in fraud prevention: Evidence from Jordanian banking industry”. Canadian Social Science 7 (3) 
Sunarto. (2003). Auditing, Yogyakarta: Panduan

Wibowo, A. (2012). Pengaruh persepsi individu tentang kohesivitas kelompok kerja dan motivasi terhadap kinerja auditor BPK RI. Tesis. Yogyakarta: Magister Manajemen Universitas Gadjah Mada.

Wicaksana, M dan Budiartha, K. (2015). “Tingkat pendidikan, pengalaman kerja, komitmen profesional dan disiplin kerja auditor pada rentang waktu penyelesaian audit”.E-Jurnal Akuntansi Universitas Udayana 13 (2), 549-563

Yusri, A. (2013). Pengaruh faktor kompetensi, indepedensi dan sikap profesional auditor terhadap kualitas audit dalam meningkatkan kinerja inspektorat (Studi empiris pada inspektorat Provinsi Sulawesi Selatan). Skripsi. Tidak dipublikasi. Makassar: Jurusan Fakultas Ekonomi Unuversitas Hasanudin Makassar 